University of Nebraska - Lincoln

DigitalCommons@University of Nebraska - Lincoln

Pesticide Fate and Transport throughout Unsaturated Zones in Five Agricultural Settings, USA

Tracy C. Hancock

USGS

Mark W. Sandstrom

USGS

Jason R. Vogel

USGS, jason.vogel@ou.edu

Richard M.T. Webb

USGS

E. Randall Bayless

USGS

See next page for additional authors

Follow this and additional works at: https://digitalcommons.unl.edu/usgsstaffpub

Part of the Earth Sciences Commons

Hancock, Tracy C.; Sandstrom, Mark W.; Vogel, Jason R.; Webb, Richard M.T.; Bayless, E. Randall; and Barbash, Jack E., "Pesticide Fate and Transport throughout Unsaturated Zones in Five Agricultural Settings, USA" (2008). USGS Staff -- Published Research. 23.

https://digitalcommons.unl.edu/usgsstaffpub/23

This Article is brought to you for free and open access by the US Geological Survey at DigitalCommons@University of Nebraska - Lincoln. It has been accepted for inclusion in USGS Staff -- Published Research by an authorized administrator of DigitalCommons@University of Nebraska - Lincoln. 


\section{Authors}

Tracy C. Hancock, Mark W. Sandstrom, Jason R. Vogel, Richard M.T. Webb, E. Randall Bayless, and Jack E. Barbash 


\title{
Pesticide Fate and Transport throughout Unsaturated Zones in Five Agricultural Settings, USA
}

\author{
Tracy C. Hancock, * Mark W. Sandstrom, Jason R. Vogel, Richard M.T. Webb, E. Randall Bayless, and Jack E. Barbash UsGS
}

Pesticide transport through the unsaturated zone is a function of chemical and soil characteristics, application, and water recharge rate. The fate and transport of 82 pesticides and degradates were investigated at five different agricultural sites. Atrazine and metolachlor, as well as several of the degradates of atrazine, metolachlor, acetochlor, and alachlor, were frequently detected in soil water during the 2004 growing season, and degradates were generally more abundant than parent compounds. Metolachlor and atrazine were applied at a Nebraska site the same year as sampling, and focused recharge coupled with the short time since application resulted in their movement in the unsaturated zone $9 \mathrm{~m}$ below the surface. At other sites where the herbicides were applied 1 to $2 \mathrm{yr}$ before sampling, only degradates were found in soil water. Transformations of herbicides were evident with depth and during the 4-mo sampling time and reflected the faster degradation of metolachlor oxanilic acid and persistence of metolachor ethanesulfonic acid. The fraction of metolachlor ethanesulfonic acid relative to metolachlor and metolachlor oxanilic acid increased from 0.3 to $>0.9$ at a site in Maryland where the unsaturated zone was $5 \mathrm{~m}$ deep and from 0.3 to 0.5 at the shallowest depth. The flux of pesticide degradates from the deepest sites to the shallow ground water was greatest (3.0-4.9 $\left.\mu \mathrm{mol} \mathrm{m} \mathrm{m}^{-2} \mathrm{yr}^{-1}\right)$ where upland recharge or focused flow moved the most water through the unsaturated zone. Flux estimates based on estimated recharge rates and measured concentrations were in agreement with fluxes estimated using an unsaturated-zone computer model (LEACHM).

Published in J. Environ. Qual. 37:1086-1100 (2008). doi:10.2134/jeq2007.0024

Received 12 Jan. 2007.

*Corresponding author (thancock@usgs.gov).
$T_{8}^{t}$ HE widespread presence of pesticides and their degradates in ground water of the USA has been documented in several large-scale studies and numerous small-scale investigations over the past four decades (Hallberg, 1989; Gustafson, 1993; Barbash and Resek, 1996; Gilliom et al., 2006). Although the relative importance of point versus nonpoint sources of pesticides in ground water has been a topic of debate, available evidence indicates that the routine application of pesticides to the land in agricultural and nonagricultural areas represents one of the principal nonpoint sources of these compounds and their degradates in ground water (Barbash and Resek, 1996). However, not all the processes and factors that control the transport and fate of these chemicals within the unsaturated zone en route to the water table are well understood.

Field studies of pesticides in the unsaturated zone can identify which compounds are transported from the land surface to the water table, especially in relation to their respective sorption properties and degradation rates. For example, pesticide compounds within the same chemical class may show similar patterns of persistence in a given environmental setting, but variations in structure among compounds within the same chemical class may also result in substantial variations in reactivity in the same medium (Mackay et al., 1997; Barbash, 2007). For most pesticide degradates, data for many parameters related to sorption and persistence are not available in the published literature, making it difficult to predict their persistence and rates of transport to the water table.

The intensity of pesticide use is a significant predictor of pesticide detections in ground water (e.g., Barbash et al., 1999), but soil properties (e.g., permeability, available water capacity, and organic carbon content) and land management practices (e.g., the use of subsurface drains, irrigation, and conservation tillage) also seem to be important controlling factors (Barbash and Resek, 1996). Improvements in the accuracy with which the presence of pesticides and their degradates in ground water can be predicted, therefore, are dependent on the acquisition of a more thorough understanding of the transport and fate of these compounds in the unsaturated zone-topics that have

T.C. Hancock, U.S. Geological Survey, 1730 East Parham Road, Richmond, VA 23228; M.W. Sandstrom and R.M.T. Webb, U.S. Geological Survey, P.O. Box 25046, MS 407, Lakewood, CO 80225-0046; J.R. Vogel, U.S. Geological Survey, 5231 South 19 Street, Lincoln, NE 68512; E.R. Bayless, U.S. Geological Survey, 5957 Lakeside Boulevard, Indianapolis, IN 46278; J.E. Barbash, U.S. Geological Survey, 934 Broadway, Suite 300, Tacoma, WA 98402.

Abbreviations: BSFOD, branched, serial, first-order decay; DEA, deethylatrazine; ESA, ethanesulfonic acid; $f_{\text {oc }}$ mass fraction of organic carbon in the soil; $K_{\mathrm{d}^{\prime}}$ soil-water distribution coefficient; $K_{\text {oc' }}$ organic carbon-normalized distribution coefficient; LEACHM, Leaching Estimation And CHemistry Model; OXA, oxanilic acid; RZWQM, Root Zone Water Quality Model. 
been summarized by a number of reviews (e.g., Barbash and Resek, 1996; Flury, 1996; Bergström and Stenström, 1998).

The movement of agricultural chemicals and their degradates through the subsurface is governed primarily by their transport in water. Typically, the movement of water and solutes through the subsurface has been assumed to occur by uniform transport (i.e., by migration within a single, homogeneous flow regime analogous to piston flow). However, the transport pathways along which pesticides and their degradates move from the land surface through the unsaturated zone to ground water are highly variable in space and time. Evidence from more than three decades of research has established that nonuniform or preferential transport in the subsurface is likely to be encountered - and may even be common — within a wide variety of hydrogeologic settings (Barbash and Resek, 1996; Flury, 1996; Kjaer et al., 2001; McMahon et al., 2006).

One consequence of this phenomenon is that substantial amounts of pesticides and their degradates may move rapidly through more mobile regions in the unsaturated zone in response to individual recharge events, thereby bypassing most of the rest of the soil matrix (Barbash and Resek, 1996). The downward movement of water and solutes may also be more rapid beneath localized, topographically low areas, a phenomenon known as "focused recharge" (Delin and Landon, 2002).

Although 42 pesticides and 40 of their selected degradates were targeted in this study (Capel et al., 2008), the compounds that were the primary focus included several chloroacetanilide and triazine herbicides and organophosphorous insecticides, which are among the most abundant and widely used pesticides in US agriculture (Kiely et al., 2004). The most commonly used chloroacetanilide herbicides include acetochlor (2-chloro- $N$ (ethoxymethyl)- $N$-(2-ethyl-6-methylphenyl)acetamide), alachlor (2-chloro- $N$-(2,6-diethylphenyl)- $N$-(methoxymethyl)acetamide), and metolachlor (2-chloro- $N$-(2-ethyl-6-methylphenyl)- $N$-(2methoxy-1-methylethyl)acetamide). Among the triazine herbicides, the most extensively used compounds include atrazine (6-chloro- $N$-ethyl- $N^{\prime}$ - (1-methylethyl)-1,3,5 triazine-2,4-diamine) and simazine (6-chloro- $N, N^{\prime}$-diethyl-1,3,5-triazine-2,4-diamine). The most commonly used organophosphorous insecticides include chlorpyrifos (O,O-diethyl O-(3,5,6-trichloro-2-pyridinyl) phosphorothioate), diazinon (O,O-diethyl O-[6-methyl-2-(1methylethyl)-4-pyrimidinyl] phosphorothioate), and malathion (di ethyl[(dimethoxyphosphinothioyl)thio]butanedioate).

The two most common pesticide classes discussed in this article are the chloroacetanilide and triazine herbicides. In general, compounds in these classes undergo transformation relatively rapidly in aerobic soil and more slowly in water (Capel et al., 2008). The chloroacetanilide herbicides may be transformed by a relatively large number of different pathways (most of them microbially mediated), resulting in the production of at least 12 different degradates for acetochlor, 22 for alachlor, and 21 for metolachlor (Stamper and Tuovinen, 1998; Lee and Strahan, 2003; Hladik et al., 2005). The degradates that have been examined most extensively for alachlor, acetochlor, and metolachlor have been their ethanesulfonic acid (2-oxoethanesulfonic acid [ESA]) and oxanilic acid (2-oxoacetic acid [OXA]) metabolites. Using the examples of metolachlor and atrazine, Capel et al. (2008) illustrate the pathways by which these two classes of herbicides are transformed.

The purpose of this study was to measure the concentrations and spatial distributions of agricultural pesticides in the unsaturated zone beneath five different agricultural settings to examine the relative importance of different factors in controlling the movement and storage of the compounds above the water table. The relative importance of different chemical properties, time elapsed since application, timing and magnitude of significant hydrologic events (rain or irrigation), and recharge rate were examined by comparing the spatial distributions and concentrations of a wide range of current-use pesticides among several sites with substantial differences in their soil properties, water table depths, and climatic conditions. In some agricultural settings, lysimeters located in areas with different rates of recharge (i.e., upslope vs. downslope) were used to examine the effects of spatial variations in the rate of recharge and the importance of focused recharge (from rain or irrigation water) on pesticide transport.

This investigation represents one of the first large-scale studies of the occurrence of current-use pesticides in the unsaturated zone that have included a large number of their degradate compounds. Comparisons between the amounts of pesticides entering the unsaturated zone (including the targeted pesticide degradates) and the amount exported to the water table provide an indication of the influence of the unsaturated zone on the transport and fate of pesticides through the subsurface. Computer models were used at the Maryland site to examine the relative importance of different physical, hydrologic, and chemical processes (including preferential flow) in controlling the transport and fate of these compounds within the unsaturated zone. Such information, coupled with an understanding of local hydrogeology and agricultural practices at each of the study sites, will help to enhance current understanding of the various processes and factors that govern the transport and fate of pesticides and their degradates in the unsaturated zone.

\section{Materials and Methods}

\section{Site Descriptions}

The field sites for this study were located in five watersheds: Merced River, California (CA); Sugar Creek, Indiana (IN); Morgan Creek, Maryland (MD); Maple Creek, Nebraska (NE); and Granger Drain, Washington (WA). Descriptions and maps of these sites are published in a separate publication (Capel et al., 2008), which provides an introduction to this series of articles in this issue. Detailed descriptions of the environmental settings of each site were provided by Fredrick et al. (2006), Gronberg and Kratzer (2006), Hancock and Brayton (2006), Lathrop (2006), and Payne et al. (2007). In CA, MD, and WA, unsaturated zone studies were conducted in one agricultural field. In NE and IN, studies were conducted at two different locations. These were designated as the NE ground water flowpath study site (herein referred to as the NE East site), the NE small watershed study site (herein referred to as the NE West site), and the IN North and South sites (Table 1).

These watersheds and field sites represent a variety of climatic conditions, soil and sediment types, cropping patterns, 
Table 1. Characteristics of the unsaturated zone and agricultural practices at five study sites across the USA.

\begin{tabular}{|c|c|c|c|c|c|c|c|}
\hline \multirow{2}{*}{$\begin{array}{l}\text { Unsaturated zone } \\
\text { characteristic }\end{array}$} & \multirow[b]{2}{*}{ California } & \multicolumn{2}{|c|}{ Indiana } & \multirow[b]{2}{*}{ Maryland } & \multicolumn{2}{|c|}{ Nebraska } & \multirow[b]{2}{*}{ Washington } \\
\hline & & North site & South site & & East site & West site & \\
\hline Climate & arid to semi-arid & humid & humid & humid to subtropical & humid & humid & arid \\
\hline Annual rainfall, $\mathrm{m} \dagger$ & 0.27 & 1.11 & 1.11 & 1.00 & 0.71 & 0.71 & 0.19 \\
\hline $\begin{array}{l}\text { Average unsaturated } \\
\text { zone thickness, } \mathrm{m} \neq\end{array}$ & 7.2 & 1.1 & 1.1 & 10.6 & 22 & $>60$ & 4.4 \\
\hline Drainage & well & poor & poor & moderate to well & well & well & well \\
\hline Soil texture & sandy loam & $\begin{array}{l}\text { silty clay loam } \\
\text { to clay loam }\end{array}$ & $\begin{array}{l}\text { silty clay loam to } \\
\text { clay loam }\end{array}$ & $\begin{array}{l}\text { silty sandy loam to } \\
\text { medium sand }\end{array}$ & silty loam & silty loam & fine sandy loam \\
\hline $\begin{array}{l}\text { Sedimentary geology } \\
\text { (from shallow to deep) }\end{array}$ & $\begin{array}{l}\text { medium sand (thin } \\
\text { silt layer } \sim 3.3 \mathrm{~m} \text { ) }\end{array}$ & $\begin{array}{l}\text { relatively } \\
\text { impermeable } \\
\text { glacial till and } \\
\text { sediments }\end{array}$ & $\begin{array}{l}\text { relatively } \\
\text { impermeable } \\
\text { glacial till and } \\
\text { sediments }\end{array}$ & $\begin{array}{l}\text { thin layer of quartz } \\
\text { sands and gravels over } \\
\text { coarsening upward } \\
\text { muddy glauconitic sand }\end{array}$ & $\begin{array}{l}\text { loess over } \\
\text { terraced sand and } \\
\text { gravel deposits }\end{array}$ & $\begin{array}{l}4 \mathrm{~m} \text { of loess } \\
\text { over glacial till }\end{array}$ & $\begin{array}{l}\text { 3-10 m of flood- } \\
\text { deposited beds of } \\
\text { sandy silt dissected by } \\
\text { subvertical clastic dikes }\end{array}$ \\
\hline \multicolumn{8}{|c|}{ Agricultural practices-2004 } \\
\hline Crop & almonds & soybeans & soybeans & soybeans & corn & soybeans & corn \\
\hline $\begin{array}{l}\text { Crop dates: planting, } \\
\text { harvest }\end{array}$ & NA & 30 Apr., 24 Sept. & 5 May, 24 Sept. & 1 Apr., 15 Oct. & 9 May, 1 Oct. & 1 May, 1. Oct. & 1 May, 15 Sept. \\
\hline Tillage & no till & reduced till & reduced till & no till & no till & no till & till \\
\hline Tile drains & no & $\sim 1 \mathrm{~m}$ deep & $\sim 1 \mathrm{~m}$ deep & no & no & no & no \\
\hline Irrigation & sprinkler & none & none & none & $\begin{array}{l}\text { center pivot } \\
\text { sprinkler }\end{array}$ & none & rill \\
\hline Irrigation amount, m & 1.07 & - & - & - & 0.25 & - & 1 \\
\hline $\begin{array}{l}\text { Pesticide application } \\
\text { method }\end{array}$ & spray & spray & spray & spray & spray & spray & spray \\
\hline $\begin{array}{l}\text { Pesticide, rate } \\
\left(\mathrm{kg} \mathrm{ha}^{-1}\right) \text {, date applied }\end{array}$ & $\begin{array}{l}\text { simazine, 0.25, } 23 \text { Apr. } \\
\text { and } 24 \text { Dec.; 2,4-D } \\
\text { dimethylamine salt, } \\
\text { 1.9, } 23 \text { Apr.; 0.5, } 24 \\
\text { Dec.; trifluralin, 1.0, } 16 \\
\text { July; chlorpyrifos, 1.1, } \\
29 \text { June }\end{array}$ & none & none & none & $\begin{array}{l}\text { atrazine, } 0.90,9 \\
\text { May and } 1.12, \\
\text { after planting; } \\
\text { metolachlor, } 0.67 \text {, } \\
9 \text { May; chlorpyrifos, } \\
0.56,5 \text { July }\end{array}$ & none & $\begin{array}{l}\text { suspect acetochlor } \\
\text { applied, rate unknown } \\
\text { but recommended at } \\
2.0 \mathrm{~kg} \mathrm{ha}^{-1} \sim 18 \text { June } \\
2004\end{array}$ \\
\hline \multicolumn{8}{|c|}{ Agricultural characteristics before $2004 \S$} \\
\hline Typical crop rotation & almonds & $\begin{array}{l}\text { 2-yr: corn, } \\
\text { soybeans }\end{array}$ & $\begin{array}{l}\text { 2-yr: corn, } \\
\text { soybeans }\end{array}$ & $\begin{array}{l}\text { 2-yr: corn, soybeans with } \\
\text { winter wheat as cover } \\
\text { crop, except } 2003 \text { was in } \\
\text { soybeans }\end{array}$ & $\begin{array}{l}\text { 2-yr: corn, } \\
\text { soybeans; no } \\
\text { cover crops }\end{array}$ & $\begin{array}{l}\text { 2-yr: corn, } \\
\text { soybeans; no } \\
\text { cover crops }\end{array}$ & $\begin{array}{l}\text { pumpkins, corn, } \\
\text { asparagus }\end{array}$ \\
\hline Pesticides & $\begin{array}{l}\text { simazine, 2,4-D, } \\
\text { chlorpyrifos }\end{array}$ & $\begin{array}{l}\text { atrazine, } \\
\text { acetochlor }\end{array}$ & $\begin{array}{l}\text { atrazine, } \\
\text { acetochlor, } \\
\text { chlorpyrifos }\end{array}$ & $\begin{array}{l}\text { atrazine, metolachlor, } \\
\text { simazine, 2,4-D, dicamba }\end{array}$ & $\begin{array}{l}\text { atrazine, } \\
\text { acetochlor, } \\
\text { metolachlor, } \\
\text { chlorpyrifos }\end{array}$ & $\begin{array}{l}\text { trifluralin, } \\
\text { acetochlor, } \\
\text { chlorpyrifos }\end{array}$ & unknown \\
\hline
\end{tabular}

† Domagalski et al. (2008).

‡ Based on minimum and maximum measured water levels at times of sampling.

$\S$ Known to have been applied in 2003.

irrigation requirements, and unsaturated zone thicknesses (Table 1). The climate at the different sites ranges from arid/ semiarid in the western watersheds (WA and CA) to humid/ subtropical in the mid-continent and eastern watersheds (NE, $\mathrm{IN}$, and MD). Soil characteristics and sediment types among the different sites vary according to the depositional environment and history of each area. The main crop types at the humid/subtropical sites are corn and soybeans (grown in rotation); these crops are primarily dependent on precipitation, but some irrigation is used at the NE East site. At the western sites (CA and WA), extensive irrigation supports orchards, vineyards, and some row crops and pasture. At the NE East site ground water is pumped for irrigation, whereas at the WA and CA sites irrigation water is diverted from nearby canals. The thickness of the unsaturated zone (i.e., the depth to the water table) was generally $10 \mathrm{~m}$ or less at the CA, IN, MD, and WA sites, reached a maximum of $22 \mathrm{~m}$ at the NE East site, and was at least $60 \mathrm{~m}$ at the NE West site.

\section{Installation, Sampling, and Analysis}

A detailed description of the overall study design, instrumentation, and chemical analyses can be found in the introductory article for this series by Capel et al. (2008). At each study location, multiple suction lysimeters were installed at various depths in the unsaturated zone for the collection of water samples (Table 2). Lysimeters were installed 3 to 15 mo before the first sampling for pesticides, which took place at the beginning of the 2004 agricultural growing season. Each lysimeter was $30 \mathrm{~cm}$ long and $5 \mathrm{~cm}$ in diameter and consisted of a PVC tube with a porous ceramic cup at the bottom and two nylon access tubes at the top that extended to the land surface. Water samples were obtained by applying a vacuum to the lysimeter for at least $3 \mathrm{~h}$ before sampling. The sample was extracted from the lysimeter by applying a positive pressure to one of the access tubes and collecting the sample that flowed out from the other tube. Lysimeters were sampled at least six times throughout the 2004 agricultural growing season at each site. Unsaturated zone water samples were analyzed for 42 pesticides and 


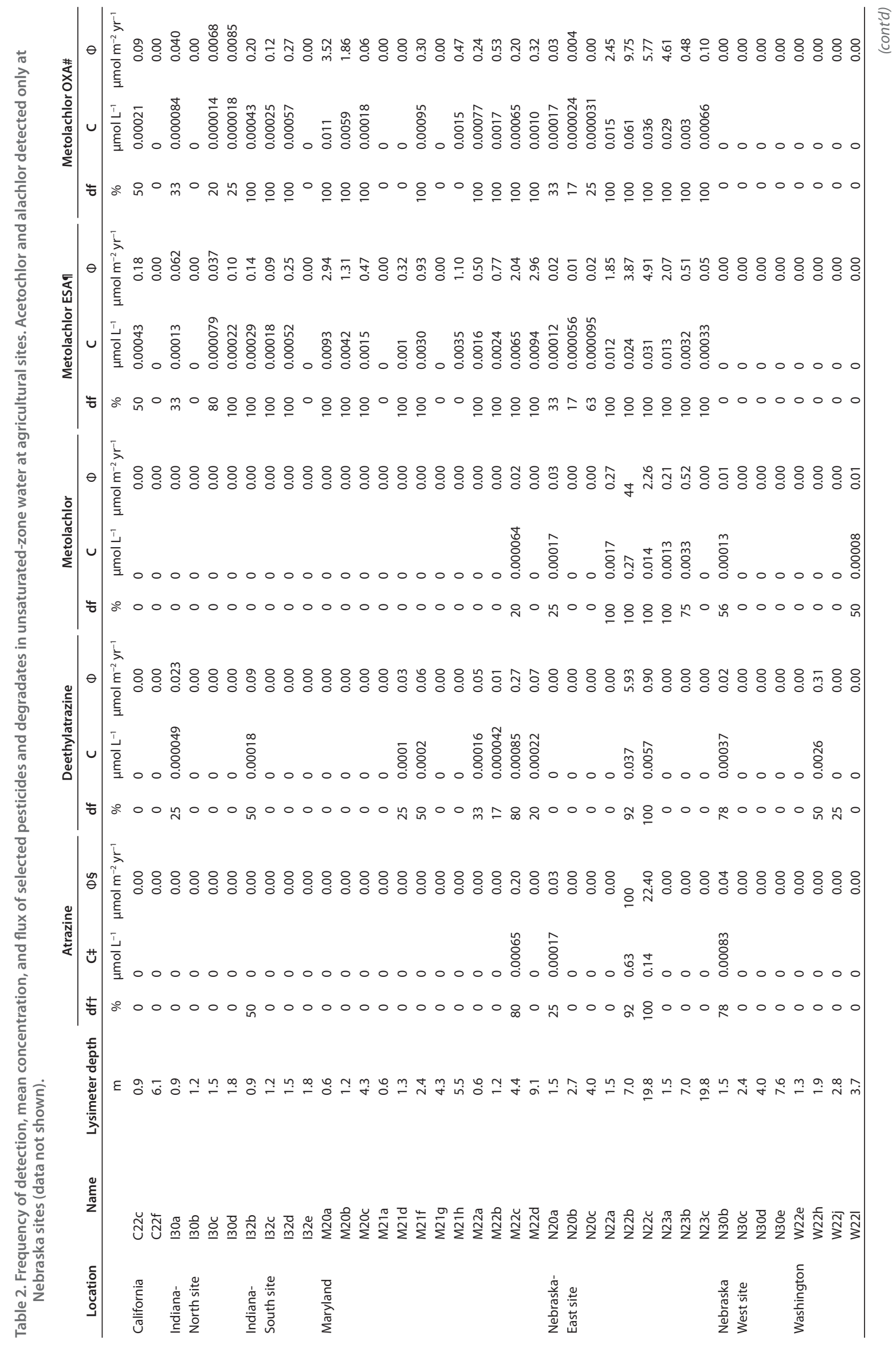




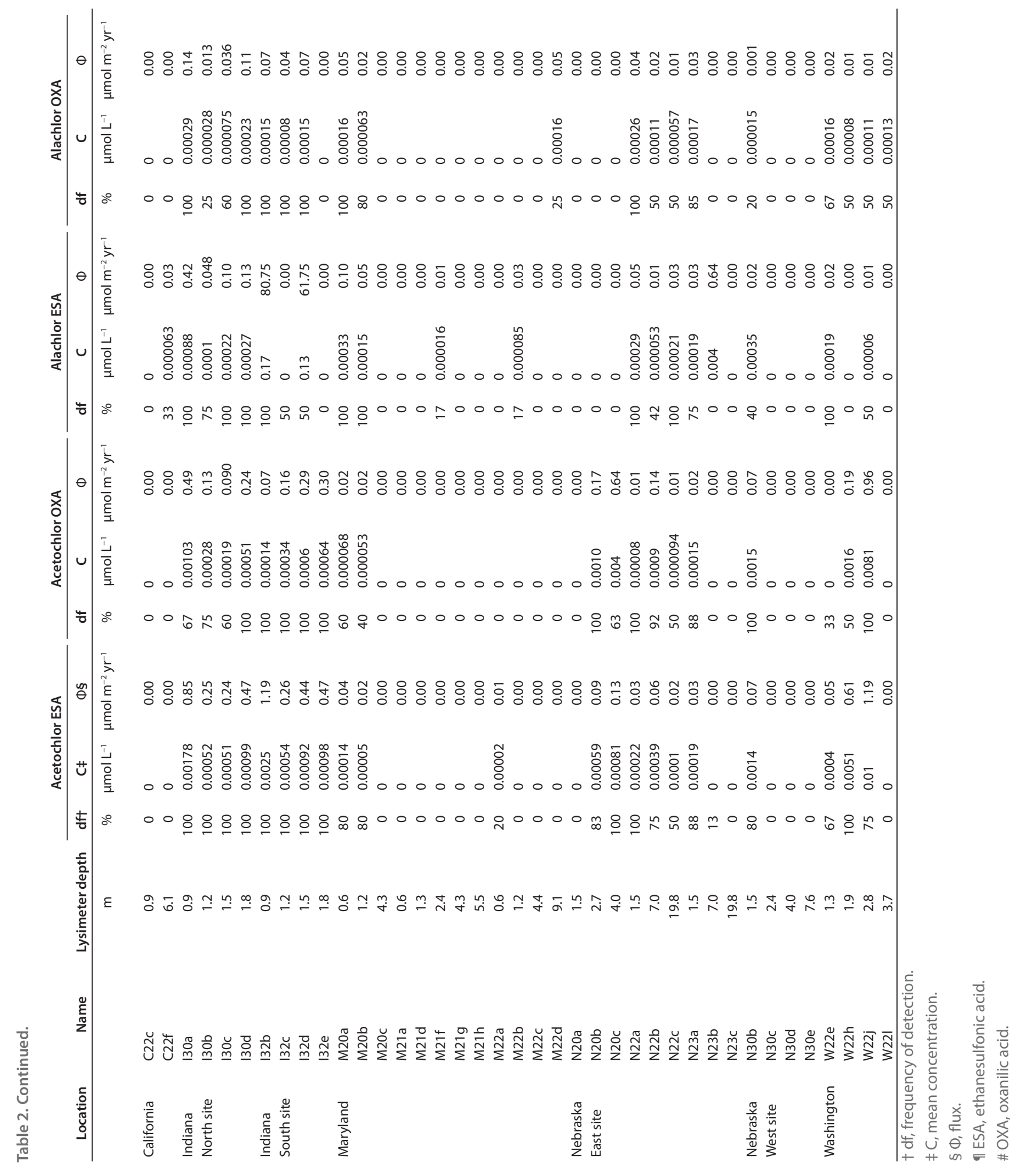


40 of their selected degradates according to the analytical protocols described by Capel et al. (2008).

Solid cores (soil and sediment) were collected during the installation of lysimeters from selected locations in the unsaturated zones of most sites according to protocols presented in Capel et al. (2008). Most cores were collected, at 1.5-m intervals, from the land surface to the water table. At some sites, cores were collected only at the depth of the lysimeters. The methods used to determine the organic matter content, bulk density, moisture content, particle size distribution, extractable anions, and concentrations of selected pesticides and degradates in the soil and sediment cores are described by Capel et al. (2008).

In another companion article in this issue, Fisher and Healy (2008) infer the rates of water movement and storage in the subsurface on the basis of meteorological observations, measurements of soil moisture and tension, and water table fluctuations. Nolan et al. (2006) evaluated the factors influencing ground water recharge at these sites using chloride concentrations in the unsaturated zone and ground water samples.

Also in this issue, Vogel et al. (2008) present information on the collection and analysis of pesticides and degradates examined in wet deposition (rain) at these sites. Pesticide concentrations were quantified in rain at all locations except WA, where rainfall is minimal and generally occurs during the nongrowing season (Payne et al., 2007). For this study, information on the use of irrigation water from ground water pumping and surface water diversions from nearby canals was gathered from local farmers and water control boards.

Farm management practices used during $2 \mathrm{yr}$ of the study (water years 2003 and 2004) were documented by gathering information from local farmers, commercial applicators of farm chemicals, and Cooperative Extension Agents from the U.S. Department of Agiculture. This information included crop type and planting and harvest dates; pesticide types, amounts, and application dates; tillage practices; and use of tile drains and irrigation (Table 1). The information was supplemented by the results from reconnaissance of the sites by study personnel.

\section{Data Analysis}

\section{Degradate Fraction}

To examine spatial and temporal variations in the proportion of a given pesticide that was present in the form of the parent compound or any of its degradates, the following quantity, referred to as the "fraction" of the compound in question, was computed for each degradate of interest:

Fraction of degradate i

$$
=\left[\text { Degradate }_{i}\right]\left([\text { Parent }]+\sum_{j=1}^{n}\left[\text { Degradate }_{j}\right]\right)
$$

where $1 \leq \mathrm{i} \leq \mathrm{n}$, and the brackets are used to denote molar concentrations (Steele et al., 2008). In the case where only a single degradate is examined $(n=1)$ for a particular parent compound, a fraction value of unity indicates that only the degradate was present
Table 3. Partition coefficients for atrazine and deethylatrazine at Maryland Site M22.†

\begin{tabular}{ccccccc} 
& & \multicolumn{2}{c}{ Atrazine\# } & & \multicolumn{2}{c}{ Deethylatrazine } \\
\cline { 3 - 4 } \cline { 6 - 7 } Name & Lysimeter depth & $K_{\mathrm{d}} \ddagger$ & $K_{\mathrm{oc}} \S$ & & $K_{\mathrm{d}}$ & $K_{\mathrm{oc}}$ \\
\hline & $\mathrm{m}$ & $\mathrm{mL} \mathrm{g}^{-1}$ & $\mathrm{~mL} \mathrm{~g}^{-1} \mathrm{OC}$ & & $\mathrm{mL} \mathrm{g}^{-1}$ & $\mathrm{~mL} \mathrm{~g}^{-1} \mathrm{OC}$ \\
M22a & 0.58 & & & 17.8 & 1980 \\
M22b & 1.22 & & & 6.32 & 488 \\
M22c & 4.42 & 2.07 & 296 & & 2.60 & 371 \\
M22d & 9.05 & & & & 1.83 & 203 \\
\hline
\end{tabular}

†These calculations used data on soil properties from solid samples collected on 23 Oct. 2003 and chemical analysis of water collected from the lysimeters on 30 Sept. 2004. Values for $K_{d}$ and $K_{\text {oc }}$ for atrazine could only be calculated directly for that one sampling point.

$\neq K_{d^{\prime}}$ soil-water distribution coefficient.

$\S K_{\text {oc }}$ organic carbon-normalized distribution coefficient.

ๆ $\mathrm{OC}$, organic carbon.

\# Concentrations of atrazine in water were available for the M22c site only. and no parent compound was detected, whereas a fraction of zero indicates that only the parent compound was detected. If multiple degradates are examined for a given parent compound and the fraction is equal to one, only the degradate of interest (degradate $\left.e_{(i)}\right)$ was detected; if the fraction equals zero, then degradate ${ }_{(i)}$ was not detected, but there may have been other degradates present in addition to the parent compound.

\section{Partition Coefficients}

Soil-water distribution coefficients $\left(K_{\mathrm{d}}\right)$ and organic carbonnormalized distribution coefficients $\left(K_{\mathrm{oc}}\right)$ were calculated for atrazine and deethylatrazine (DEA) (6-chloro- $N$-(1-methylethyl)-1,3,5 triazine-2,4-diamine) from the unsaturated zone field data collected at one of the MD sites (lysimeters M22a, b, c, and d). Table 3 provides depth information for these lysimeters; other site information was provided by Capel et al. (2008). Data on analyte concentrations for the aqueous and solid phase and for the water content and porosity of the solid phase were available for most of the MD M22 lysimeter sites. However, M22c was the only lysimeter for which data on the concentrations of atrazine in water were available; consequently, values for $K_{\mathrm{d}}$ and $K_{\text {oc }}$ for atrazine could only be calculated directly for that one sampling point. By contrast, the detection of DEA in the aqueous phase at all of the MD22 sites made it possible to compute values of $K_{\mathrm{d}}$ and $K_{\text {oc }}$ at all of the MD22 sites for this degradate. These calculations used data on soil properties and analyte concentrations in the solid phase from samples collected on 23 Oct. 2003 and results from the chemical analysis of water collected from the lysimeters on 9 Sept. 2004. Values of $K_{\mathrm{d}}$ (in $\mathrm{mL} \mathrm{g}^{-1}$ dry weight) for each analyte of interest were computed by dividing its concentration in the solid phase ( $\mu \mathrm{g} \mathrm{g}^{-1}$, dry weight) by its concentration in water $\left(\mu \mathrm{g} \mathrm{mL}^{-1}\right)$ (Hamaker and Thompson, 1972). For the observed unsaturated zone data, the following equation was used for this calculation because the soil solids that were analyzed-referred to herein as the "bulk soil"—also contained the interstitial soil water:

$$
K_{\mathrm{d}}=\frac{\left(C_{\mathrm{a}, \mathrm{b}}-C_{\mathrm{a}, \mathrm{w}}\right) / \rho_{\mathrm{b}}}{C_{\mathrm{a}, \mathrm{w}}}
$$


where $C_{\mathrm{a}, \mathrm{b}}$ is the concentration of analyte in bulk soil (water plus solids, in $\left.\mu \mathrm{g} \mathrm{mL}^{-1}\right), C_{\mathrm{a}, \mathrm{w}}$ is the concentration of analyte in water (in $\mu \mathrm{g} \mathrm{mL} L^{-1}$ ), and $\rho_{\mathrm{b}}$ is the soil bulk density (in $\mathrm{g} \mathrm{mL}^{-1}$ ), computed as follows:

$$
\rho_{\mathrm{b}}=\rho_{\mathrm{s}}(1-\phi)
$$

where $\rho_{s}$ is the particle density (assumed to be $2.65 \mathrm{~g} \mathrm{~mL}^{-1}$ ), and $\phi$ is the porosity (pore volume in $\mathrm{mL}$ per total volume in $\mathrm{mL}$ ). $K_{\mathrm{oc}}\left(\mathrm{mL} \mathrm{g}^{-1} \mathrm{OC}\right)$ was computed as follows (Hamaker and Thompson, 1972):

$$
K_{\mathrm{oc}}=\frac{K_{\mathrm{d}}}{f_{\mathrm{oc}}}
$$

where $f_{\mathrm{oc}}$ is the mass fraction of organic carbon in the soil.

\section{Pesticide Flux}

Recharge rates were calculated from fluctuations in the water table at the CA, IN, MD, and WA sites by Fisher and Healy (2008). The water table fluctuation method was not used for the NE site because that site did not have soil moisture probes and lacked the necessary environmental information to perform these calculations. However, Nolan et al. (2006) estimated recharge on the basis of chloride concentrations in the unsaturated zone and the ground water samples from the $\mathrm{NE}$ sites. The resulting recharge rates used for this study were: CA, $0.42 \mathrm{~m} \mathrm{yr}^{-1}$; IN, $0.48 \mathrm{~m} \mathrm{yr}^{-1}$; MD, $0.32 \mathrm{~m} \mathrm{yr}^{-1}$; NE East, $0.16 \mathrm{~m} \mathrm{yr}^{-1}$; NE West, $0.048 \mathrm{~m} \mathrm{yr}^{-1}$; and WA, $0.12 \mathrm{~m} \mathrm{yr}^{-1}$. For MD Site M22, recharge rates also were estimated by Webb et al. (2008) using the Leaching Estimation And CHemistry Model (LEACHM) (Hutson and Wagenet, 1992; Hutson, 2005). Recharge rates were multiplied by the mean concentrations of pesticides and degradates $\left(\mu \mathrm{mol} \mathrm{L}^{-1}\right)$ to obtain a pesticide flux estimate (in $\mu \mathrm{mol} \mathrm{m}{ }^{-2} \mathrm{yr}^{-1}$ ) for each lysimeter. For these calculations, concentrations reported as less than the detection limit were assumed to be zero.

\section{Modeling}

At the MD site, two unsaturated zone simulation models_LEACHM and the Root Zone Water Quality Model (RZWQM) (Ahuja et al., 2000) — were used to simulate the movement of water and pesticides through the unsaturated zone. A detailed description of the overall model design, input parameters, and data analysis can be found in the companion articles in this series by Webb et al. (2008) for LEACHM and Bayless et al. (2008) for RZWQM. Simulations using LEACHM and RZWQM were not conducted at other sites in this study because of time constraints or a lack of available data for one or more input variables.

Detailed LEACHM simulations for the MD site provided independent estimates of recharge and solute flux that could be compared with the results obtained using the methods used by Fisher and Healy (2008) and Nolan et al. (2006). In LEACHM, water movement was simulated using Richard's equation (via the WATer-FLOw, or WATFLO routine) (Hutson, 2005). Input data for the model simulations included meteorological observations for water years 1995 through 2004, soil texture, bulk density, organic matter, and information on the timing and loading of pesticides and bromide (applied as a conservative tracer)(Webb et al., 2008). Values for parameters related to the hydraulic properties of the soil and solute dispersivity were adjusted during calibration runs to match observed variations in soil moisture content and bromide concentrations. Climate, geology, and agricultural management information from the study site was used to build the model, and simulations of water and chemical transport were compared with measured values for soil-water tension, soil moisture, and the concentrations of pesticides and degradates.

Values for most of the parameters used during model runs to characterize the physical and chemical properties of pesticides are listed in Capel et al. (2008). The only exceptions involved estimates of $K_{\text {oc }}$ and soil aerobic half-life for atrazine, DEA, metolachlor, metolachlor ESA (2-([2-ethyl-6-methylphenyl] [2-methoxy-1-methylethyl]amino)-2-oxoethanesulfonic acid), and metolachlor OXA (2-([2-ethyl-6-methylphenyl] [2-methoxy1-methylethyl]amino)-2-oxoacetic acid). Values for these parameters were obtained from other literature sources or through model calibration using observations made at the NE East site, where the largest number of these compounds was detected simultaneously. Calibrated transformation rates were obtained using a branched, serial, first-order decay (BSFOD) model in LEACHM (Webb et al., 2008). Use of the BSFOD model for this purpose was based on the assumption that the sum of the rates of production of all of the degradates of interest for a given parent compound could not exceed the rate of disappearance of the parent compound. These reaction rates were estimated from temporal variations in the compound fractions (Eq. [1]) observed in samples collected from the N22b lysimeter at the NE East site (Webb et al., 2008). Because of their inherently site-specific nature, these calibrated half-life values may be substantially different from those reported by controlled laboratory studies (e.g., Gilliom et al., 2006). Pesticide transformation rates were adjusted for variations in temperature and water content but not for $\mathrm{pH}$.

For some aspects of the analysis of the results from this study, statistical tests were used to examine the significance of relations of selected variables with time or depth below the ground surface. In such cases, a significance level $(\alpha)$ of 0.05 was used.

\section{Results}

Overall, results from the chemical analysis of water and solid-phase samples indicated detectable spatial and temporal patterns in the occurrence of pesticides and their selected degradates in the unsaturated zone beneath the five sites. The majority of compounds analyzed in this study were not detected in the aqueous or the solid phases sampled (Capel et al., 2008). However, in general, more compounds were detected in unsaturated zone water from the NE, WA, and MD locations than from the IN and CA locations.

\section{Unsaturated Zone Solids}

Few pesticides and degradates were detected in the solid samples obtained from the unsaturated zone beneath the study sites. 
Because of operational difficulties, solid-phase samples were not collected from the unsaturated zone of the IN or WA sites. No pesticides or degradates were detected in solid-phase samples collected from the NE site. At the CA site, the only pesticides detected in solid samples were simazine and trifluralin (2,6-dinitro- $N, N$-dipropyl-4-(trifluoromethyl)benzenamine). At the MD site, metolachlor and simazine were detected in $40 \%(n=10$, where $n$ is the number of samples analyzed) of the unsaturated zone solid samples, and dieldrin was detected in 20\% $(n=10)$. At one lysimeter in MD (M21a), diazinon and pendimethalin (N-(1-ethylpropyl)-3,4dimethyl-2,6-dinitrobenzenamine) were detected.

At the MD M22 site, located in an upland recharge area of a cropped field, atrazine and DEA were detected in 75 and $100 \%$ of the samples $(n=4)$, respectively. However, atrazine and DEA were detected less frequently under the middle and lower field sites in this location than at the upland recharge site. Atrazine and DEA concentrations in the soil were highest closest to the surface (Fig. 1) and decreased with depth in the unsaturated zone at the M22 site.

\section{Unsaturated Zone Water}

Although pesticides and degradates were rarely detected in the solid-phase samples, they were commonly detected in unsaturated zone water samples collected from lysimeters. The pesticides that were detected most frequently in water samples were the triazine and acetanilide herbicides and their degradates (Table 2). In general, degradates of atrazine, metolachlor, acetochlor, and alachlor were detected more frequently than their parent products.

Herbicides were the type of pesticide detected most frequently in the unsaturated zone water samples. At CA, no parent compounds and only a few acetanilide degradates (metolachlor ESA, metolachlor OXA, and alachlor ESA) were detected in unsaturated zone samples (Table 2). At both IN locations, metolachlor and atrazine were the only parent pesticides detected and were detected only in one sample; however, among the transformation products of interest, the acetanilide degradates were detected frequently, whereas DEA was detected less frequently. At the MD site, neither acetochlor nor alachlor were detected. Metolachlor and atrazine and their degradates were detected frequently at the MD site, whereas degradates of acetochlor and alachlor were detected less frequently. At both NE locations, several parent compounds were detected, albeit infrequently, and typically in the same sample (from the same lysimeter N22b). Results at the NE sites were similar to those at the MD site, with metolachlor and the atrazine degradates being detected most frequently and with few detections of acetochlor or alachlor degradates. At NE East Site N22b, the concentrations of metolachlor and atrazine and their degradates were the highest observed for this study. At the WA site, few parent compounds were detected, but degradates of acetochlor, alachlor, and atrazine were frequently detected.

At the CA, IN, WA, and NE West sites, none of the targeted insecticides or fungicides were detected, whereas at the MD site, none of the organophosphate insecticides or fungicides were detected. Only two degradates of the insecticide fipronil (5-amino1-[2,6-dichloro-4-(trifluoromethyl)phenyl]-4-[(trifluoromethyl)

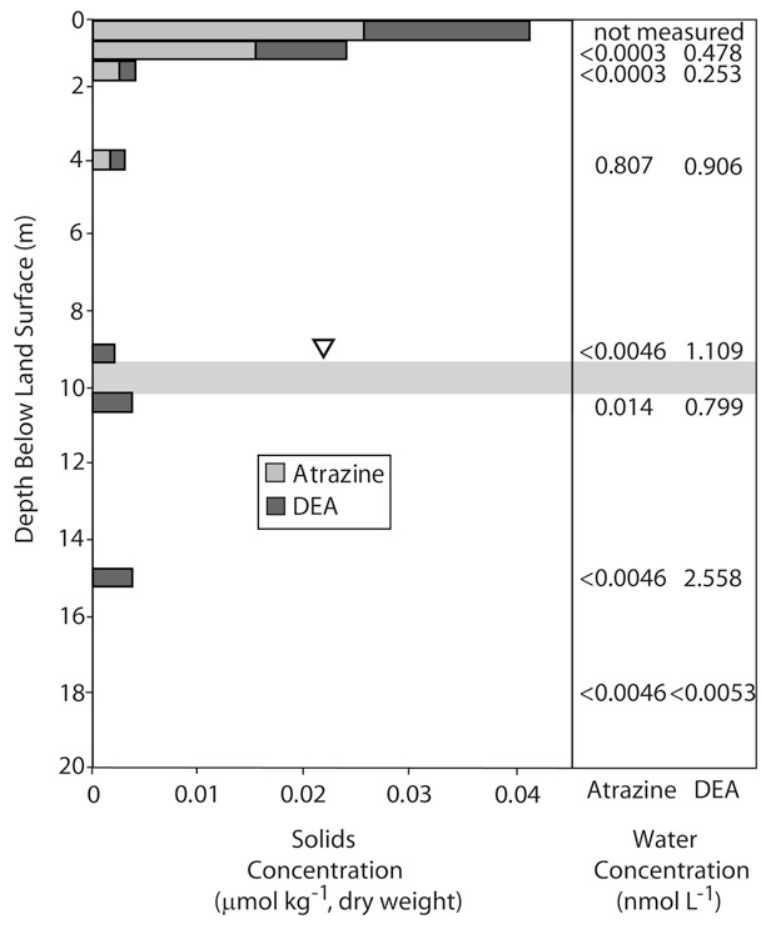

Fig. 1. Concentrations of atrazine and deethylatrazine (DEA) in solids and water at Maryland Site M22. Shaded zone at $9.7 \mathrm{~m}$ indicates range of fluctuations in depth of water table below land surface over time. See Table 3 footnotes for sampling dates.

sulfinyl]-1H-pyrazole-3-carbonitrile) were detected, fipronil sulfone (5-amino-1-[2,6-dichloro-4-(trifluoromethyl)phenyl]-4[(trifluoromethyl)sulfonyl]-1H-pyrazole-3-carbonitrile) and desulfinyl fipronilamide (5-amino-1-[2,6-dichloro-4-(trifluoromethyl) phenyl]-4-[trifluoromethyl]-1H-pyrazole-3-carboxamide), which were detected in the same sample from Site M20b. At the NE East site, the organophosphate insecticide chlorpyrifos was detected in several samples from N20b and in one sample from N20c. Metalaxyl (methyl $N$-(2,6-dimethylphenyl)- $N$-(methoxyacetyl)-DLalaninate), the only fungicide detected in this study, was found at NE East Site N22b.

\section{Discussion}

\section{Inputs to the Unsaturated Zone}

\section{Agricultural Application of Pesticides}

The detection of pesticides and their degradates in the unsaturated zone beneath these sites reflects the influence of agricultural chemical use (Table 1) over the past several years. Of the compounds examined, those detected most frequently were the triazine and acetanilide herbicides - specifically, atrazine, metolachlor, acetochlor, and alachlor - and their degradates (although the data are not shown in Table 2, acetochlor and alachlor were both detected in lysimeters at the N22 and N30 sites in Nebraska). Among the pesticides for which the chemical analyses were conducted, the triazine and acetanilide herbicides are known to have been applied with the greatest frequencies and in the largest quantities at the IN, MD, and NE sites (Table 1 and Capel et al., 2008). At the CA and WA sites, few pesticides were detected. However, among the triaz- 


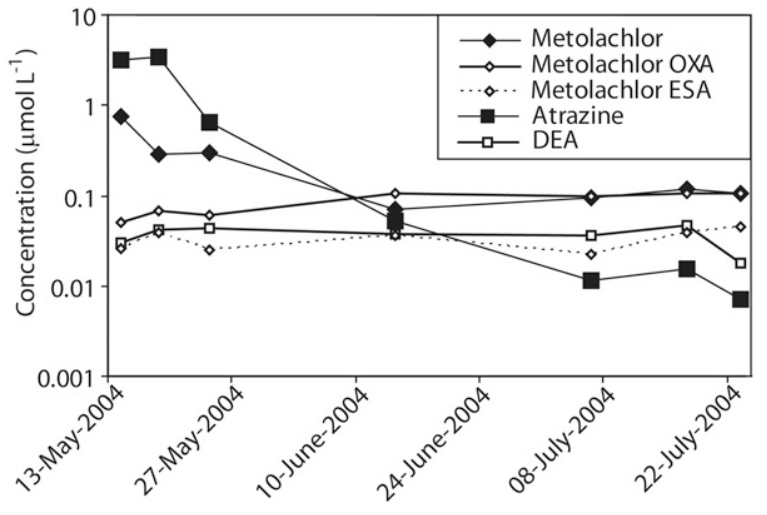

Fig. 2. Concentrations of metolachlor, atrazine, and degradates over time at Nebraska Site N22b, located $7 \mathrm{~m}$ below land surface. DEA, deethylatrazine; ESA, ethanesulfonic acid; OXA, oxanilic acid.

ine and acetanilide herbicides, only simazine was known to have been used. Much of the following discussion focuses on the results for the triazines and acetanilides for the IN, MD, and NE sites.

At the MD site, $2 \mathrm{yr}$ had passed since the last application of metolachlor, atrazine, or simazine on corn in 2002; soybeans were planted in 2003 and 2004. Few, if any, of the parent compounds analyzed were detected in unsaturated zone water samples. This was attributed to the potential influence of a variety of factors, including the time elapsed between application and sampling, the physical and chemical characteristics of the chemicals (water solubility, sorptive properties, and degradation rates), the characteristics of the soil, and water flux at the site. The effects of these factors are discussed in later sections.

At the NE East site, atrazine and metolachlor were applied during the sampling period in 2004 and in previous years. At both of the NE sites, acetochlor was applied 1 yr before sample collection. These parent compounds and their degradates were detected frequently in unsaturated zone water samples from these sites (Table 2; data for acetochlor and alachlor not shown). At both IN sites, 1 yr had passed since the last application of atrazine and acetochlor, and at least $2 \mathrm{yr}$ had passed since metolachlor had been used. Few parent compounds were detected at the IN sites. Among the transformation products, acetanilide degradates were frequently detected, but DEA was less frequently detected. The degradate acetochlor sulfinylacetic acid (SAA) (2-(\{[N-(ethoxymethyl)- $N-(6-$ ethyl-2-methylphenyl)carbamoyl] methyl\}sulfinyl) acetic acid) was detected more frequently and at higher concentrations at the IN and NE sites than at the other sites in this study. Because its degradate fraction (Eq. [1]) was observed to decrease with increasing subsurface residence time (data not shown), acetochlor SAA may be a short-lived intermediate transformation product; its presence in the unsaturated zone may therefore be an indication of recent application of its parent compound (acetochlor) to the land surface. Studies conducted under controlled laboratory conditions are needed to characterize the persistence of this degradate.

\section{Rain and Irrigation}

Another input mechanism by which pesticides may reach the unsaturated zone is rainfall. The concentrations of pesticides and degradates were measured in wet deposition (rain) by Vogel et al.
(2008). In general, the amounts of herbicides deposited to these fields from rain (and thus potentially entering the unsaturated zone) were minor in comparison with the amounts commonly applied to the land surface for agricultural purposes, usually representing less than 1\% of the applied mass (Vogel et al., 2008).

Irrigation water can also add pesticides to the land surface and, hence, the unsaturated zone. At the NE East location, ground water is pumped for irrigation, whereas at the CA and WA locations, surface water transported in canals is used for irrigation. Samples of irrigation-well and canal water taken from these sites were therefore analyzed for the same suite of pesticides and degradates examined in the lysimeter samples.

Canal water used for irrigation at the CA location did not contain detectable levels of pesticides. At the WA and NE East locations, several pesticides and degradates were detected in irrigation water. At the NE East site, several triazine and acetanilide pesticides and degradates were detected in water samples from wells completed at 28 and $32 \mathrm{~m}$ below land surface and screened in the same hydrologic unit as the irrigation well. In particular, metolachlor ESA and alachlor ESA were detected at concentrations of up to $8 \times 10^{-4} \mu \mathrm{mol} \mathrm{L} \mathrm{L}^{-1}$ $\left(0.26 \mu \mathrm{g} \mathrm{L}^{-1}\right)$. Several triazine and acetanilide pesticides and degradates and organophosphorus insecticides (including diazinon and chlorpyrifos) were detected in irrigation water from the canal in WA. Acetanilide and triazine herbicides were detected at concentrations of up to $3 \times 10^{-4} \mu \mathrm{mol} \mathrm{L} \mathrm{L}^{-1}$ $\left(0.1 \mu \mathrm{g} \mathrm{L}^{-1}\right)$. These observations suggest that irrigation water contributed negligible amounts of all applied pesticide compounds relative to the amounts applied directly to the crops.

\section{Focused Recharge and Nonmatrix Flow}

Major hydrologic events (irrigation or rain) can cause surface ponding and thus the focused recharge of water. This phenomenon can cause much of the infiltrating water to bypass the more biologically and chemically reactive root zone, allowing relatively high concentrations of unreacted parent compounds to move deeper in the unsaturated zone. This results in an increased flux of pesticides to the unsaturated zone relative to other areas nearby (Flury, 1996; Tasli et al., 1996; Iqbal, 1999).

On 29 Apr. 2004, more than $10 \mathrm{~cm}$ of rain-the largest daily total in more than $2 \mathrm{yr}$-fell on fields at the NE East site. This large amount of rain led to intense runoff, resulting in the ponding of water in a topographically low area near the N22 lysimeter site, located in the down-slope end rows of a corn field. Pesticides, which had recently been applied to land, were transported to this ponded area and, under conditions of focused recharge, transported rapidly downward out of the root zone, decreasing their near-surface residence time and opportunities for their transformation. This resulted in relatively high concentrations of the parent compounds in the unsaturated zone (Table 2). Figure 2 shows the elevated concentrations of pesticides and degradates from May though July 2004 for the $\mathrm{N} 22 \mathrm{~b}$ site. A similar trend in pesticide and degradate concentrations was also observed at the shallow NE East Site N22a.

The lysimeter at NE East Site N22b is installed in a loess (silt) layer just above a sand layer. Water is likely to be retained longer 
in the loess as a result of a capillary barrier effect above the sand. The resulting increase in the residence time of the water along the contact between these two horizons was presumed to have been responsible for the higher concentrations at the $\mathrm{N} 22 \mathrm{~b}$ site relative to those in other locations at the NE East site. Consistent with this, heat-dissipation and time-domain reflectometry probes at the WA site, which had soil characteristics similar to those at the NE East Site N22b, showed a pulse of moisture moving rapidly through the unsaturated zone after major periods of rain and irrigation, supporting the focused recharge hypothesis (Fisher and Healy, 2008). Measurements from heat dissipation or timedomain reflectometry probes were not available at the NE site.

Water table fluctuations driven by high-flow events in streams may also be a source of pesticides in the unsaturated zone near the streams in question. Through a process known as bank filtration, pesticide parent compounds, degradates, and other solutes that are present in the stream water may be transported downward through the streambed into the unsaturated zone beneath or immediately adjacent to the stream. After a large storm in May 2004 caused the water table to rise above the lysimeter located at the $2.7-\mathrm{m}$ depth at NE East Site N20c, increases in the concentrations of acetochlor and three of its degradates were observed in the lysimeter. The concentrations measured in samples taken from the lysimeters at this site provided evidence of degradation and downward transport of the compounds over the rest of the summer. During this period, the formation and subsequent disappearance of acetochlor SAA provided further indication of its transient nature.

\section{Storage, Transport, and Fate of Pesticides in the Unsaturated Zone}

\section{Storage}

The majority of pesticides and degradates examined for this study were not detected in water- or solid-phase samples taken from the unsaturated zone at any of the sites. Thus, most of these compounds were either taken up by the crops, retained in the root zone, carried rapidly through the unsaturated zone without being detected, or transformed in situ to other compounds for which analyses were not conducted. By contrast, atrazine and DEA were detected in many of the solid-phase samples from the unsaturated zone at MD. This section focuses primarily on the transport and persistence of these compounds at this site.

Atrazine and DEA were detected frequently in solid-phase samples from an upland recharge area of a cropped field (Site M22) and less frequently under the middle and lower field sites (M21 and M20, respectively). At Site M22, while atrazine was more prevalent than DEA in the solid phase near the land surface (Fig. 1), the concentrations of both compounds decreased with depth through the unsaturated zone. No atrazine was detected in water from the 0.6-m lysimeter (Table 2), although both atrazine and DEA were detected at greater depths. Because atrazine was not applied to this field in 2004 or 2003, but was applied in 2002 when the field was planted in corn, its presence in the near-surface solids was likely to have been a consequence of previous applications. At the M22 site, fine-grained sediments containing woody debris overlie coarse, angular gravel. In a manner similar to the capillary barrier effect discussed previously with respect to the sand/ silt contact at NE East Site N22b, gravel underlying finer-grained surface material can result in enhanced moisture retention in the finer-grained material because unsaturated gravel conducts moisture poorly. The woody debris and other refractory carbon in the overlying layer might therefore represent a low-conductivity repository in which atrazine becomes sequestered (Lesan and Bhandari, 2003), resulting in reduced contact with microorganisms and more limited exchange with mobile water (Gevao et al., 2001).

Slow leaching of atrazine from the surface was indicated by other data from the MD site. Atrazine concentrations in water samples from the lysimeter at $0.6 \mathrm{~m}$, beneath the organic-rich surface layers, increased during the summer of 2004. According to Steele et al. (2008), atrazine was detected at low concentrations in ground water near the water table beneath M22 and the other two MD sites farther down the ground water flow gradient (M20 and M21, located down-slope from the M22 site).

Values for $K_{\mathrm{d}}$ and $K_{\mathrm{oc}}$ were calculated for atrazine and DEA from the unsaturated-zone field data collected at MD lysimeters M22a, b, c, and d using Eq. [2] and [3], respectively (Table 3). The calculated $K_{\mathrm{d}}$ value for atrazine at M22c $(4.4 \mathrm{~m}$ below land surface) was $2.07 \mathrm{~mL} \mathrm{~g}^{-1}$, whereas those for DEA ranged from $17.8 \mathrm{~mL} \mathrm{~g}^{-1}$ at the near-surface MD site (M22a) to $1.83 \mathrm{~mL} \mathrm{~g}^{-1}$ at the deepest site $(\mathrm{M} 22 \mathrm{~d})$. These $K_{\mathrm{d}}$ values are similar to those reported in the literature for laboratory experiments; Seybold and Mersie (1996) reported $K_{\mathrm{d}}$ values for atrazine and DEA of 1.8 and $0.99 \mathrm{~mL} \mathrm{~g}^{-1}$, respectively.

The calculated $K_{\text {oc }}$ value for atrazine was $296 \mathrm{~mL} \mathrm{~g}^{-1} \mathrm{OC}$ (at M22c), whereas for DEA the values ranged from $1980 \mathrm{~mL} \mathrm{~g}^{-1}$ $\mathrm{OC}$ at the near-surface MD site (M22a) to $203 \mathrm{~mL} \mathrm{~g}^{-1} \mathrm{OC}$ at the deepest site (M22d) (Table 3). Such observations are not without precedent; at a single site in Champaign County, Illinois, Roy and Krapac (1994) observed variations in $K_{\mathrm{oc}}$ spanning an order of magnitude for DEA and atrazine within the soil column and observed a general decrease in $K_{\text {oc }}$ with decreasing $K_{\mathrm{d}}$. Given the fact that $K_{\mathrm{d}}$ values commonly show a direct relation with $f_{\text {oc }}$ and that $f_{\text {oc }}$ decreased with depth at the MD site (as is typically the case), the decrease in $K_{\text {oc }}$ values observed with depth at the MD site is therefore not unexpected. At the MD site, the nature of the organic carbon in the soil column likely varies with depth such that carbon in deeper layers has undergone more transformation over time. It is also possible that sorption equilibrium was not reached at this site, particularly in the upper soil column where water likely moves through the unsaturated zone rapidly.

Although the near-surface MD sites for the current study exhibited higher calculated $K_{\text {oc }}$ values than those commonly reported by previous studies, the values obtained for the deeper locations were similar to those in the literature. Mackay et al. (1997) reported a $K_{\text {oc }}$ value for atrazine of $100 \mathrm{~mL} \mathrm{~g}^{-1} \mathrm{OC}$, whereas Seybold and Mersie (1996) reported a $K_{\text {oc }}$ value for DEA of $80 \mathrm{~mL} \mathrm{~g}^{-1}$ OC. Differences between the partition coefficients computed from this study and those reported by these other authors may be attributable to differences in the soil and sediment types, moisture conditions, and the amount and type of organic material in the laboratory experiments relative to the materials at this particular field site. 

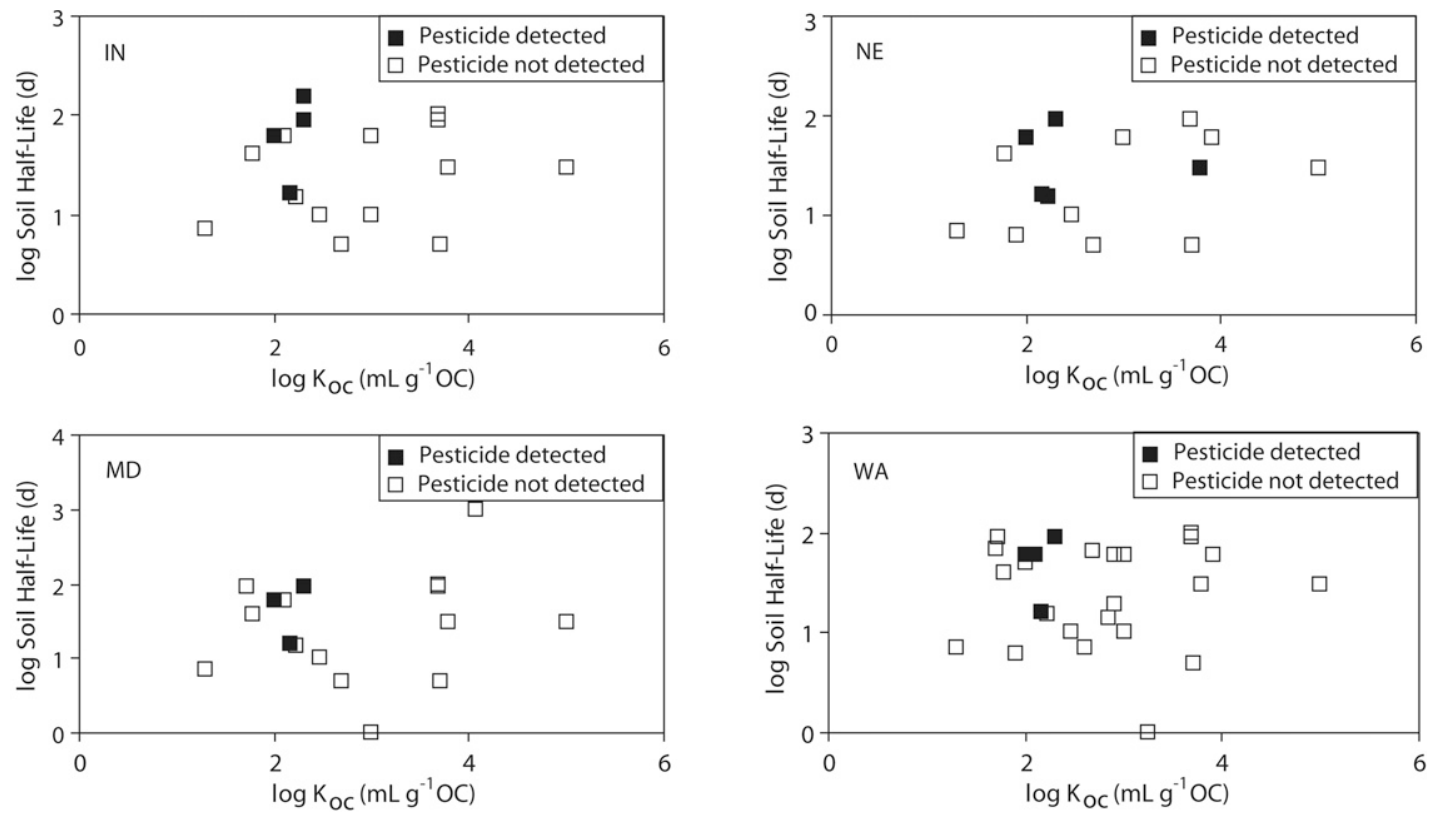

Fig. 3. The occurrence of the target pesticides in the unsaturated zone as a function of soil half-life and organic carbon-normalized distribution coefficient $\left(K_{o c}\right)$ for all parent pesticides that were applied in the counties of the study sites in Indiana (IN), Maryland (MD), Nebraska (NE), and Washington (WA), based on data gathered by Nakagaki and Wolock (2005).

The downward transport of atrazine and DEA through the unsaturated zone at MD Site M22 was simulated for the period 1 Oct. 1994 through 30 Oct. 2004 using LEACHM. The simulations used $K_{\mathrm{oc}}$ values from Bayless et al. (2008) for atrazine and DEA (234 and $110 \mathrm{~mL} \mathrm{~g}^{-1} \mathrm{OC}$, respectively) and soil aerobic half-lives from Webb and Sandstrom (2008) of 11 and 241 d, respectively, obtained through LEACHM model calibration (R.M.T. Webb and M.W. Sandstrom, personal communication, 2007). Using soil property values measured from core samples obtained during well installation at the site, a 10-m-thick unsaturated zone model was constructed. Drawing on information from local farmers, the simulations involved the application of atrazine to the land surface at a rate of $0.96 \mathrm{mmol} \mathrm{m}^{-2}\left(208 \mathrm{mg} \mathrm{m}^{-2}\right)$ before planting corn every other year from 1994 through 2004. This amounted to four applications totaling $3.86 \mathrm{mmol} \mathrm{m}^{-2}\left(832 \mathrm{mg} \mathrm{m}^{-2}\right)$ for this period; no atrazine was applied in 2004. Two weeks after the last atrazine application on $27 \mathrm{Apr}$. 2002, the simulations indicated that $0.39 \mathrm{mmol} \mathrm{m}^{-2}\left(84 \mathrm{mg} \mathrm{m}^{-2}\right)$ of atrazine remained in the $10-\mathrm{m}$ soil column, with $0.06 \mathrm{mmol} \mathrm{m}^{-2}\left(13 \mathrm{mg} \mathrm{m}^{-2}\right)$ in the top $10 \mathrm{~cm}$, decreasing mass in each 10-cm layer to a depth of $1.8 \mathrm{~m}$, and concentrations below the reporting level of $4.6 \times 10^{-7} \mathrm{\mu mol} \mathrm{dm}^{-3}$ $\left(\mu \mathrm{mol} \mathrm{L}{ }^{-1}\right)$ at greater depths. Accounting for the combined influence of the $K_{\mathrm{oc}}$ of the two compounds and the amount of organic carbon in the soils, roughly $75 \%$ of the atrazine mass and $70 \%$ of the DEA mass at any depth was sorbed to the solid phase of the soil, with the remaining fraction being present in solution. The degradation of atrazine over the 2-wk period after the 27 Apr. 2002 application produced $0.019 \mathrm{mmol}\left(4.2 \mathrm{mg}\right.$ ) of DEA per $\mathrm{m}^{2}$ in the top $10 \mathrm{~cm}$. Atrazine applications before 2002 and continued leaching resulted in the presence of $6 \times 10^{-6} \mathrm{mmol}(0.013 \mathrm{mg})$ of DEA per $\mathrm{m}^{2}$ in each $10-\mathrm{cm}$ layer deeper than $8 \mathrm{~m}$.

A snapshot of the simulated atrazine distribution on 31 Oct. 2004, more than $2 \mathrm{yr}$ after the last application on 27 Apr. 2002, inferred the following for the 10-m-deep unsaturated zone column. Of the $3.86 \mathrm{mmol} \mathrm{m}^{-2}\left(832 \mathrm{mg} \mathrm{m}^{-2}\right)$ of atrazine applied, none would have remained as the parent compound, and none would have exited from the bottom of the column; $0.87 \mathrm{mmol} \mathrm{m}^{-2}$ of atrazine would have undergone transformation to DEA, with a total of $0.18 \mathrm{mmol} \mathrm{m}^{-2}$ remaining in the $10-\mathrm{m}$ unsaturated zone column, exhibiting concentrations decreasing from approximately $4.6 \times 10^{-3} \mu \mathrm{mol} \mathrm{dm}^{-3}\left(\mu \mathrm{mol} \mathrm{L}{ }^{-1}\right)$ near the surface to $4.6 \times 10^{-5}$ $\mu \mathrm{mol} \mathrm{dm}{ }^{-3}\left(\mu \mathrm{mol} \mathrm{L}{ }^{-1}\right)$ below $8 \mathrm{~m}$. The mass of sorbed DEA predicted to have been in the unsaturated zone column was similar to that observed in the field data, but clearly atrazine is more persistent than the model predicts.

\section{Potential for Leaching to Ground Water}

The potential for a pesticide to leach through the unsaturated zone to ground water depends largely on five factors: (i) rate and timing of water flux, (ii) characteristics of the soil, (iii) rate and timing of pesticide application, (iv) sorption properties of the compound, and (v) degradation rates of the compound. For a given location, the first two factors are constant for all pesticides, whereas the last three are compound specific.

Figure 3 compares the presence or absence of parent pesticide compounds in the unsaturated zone with their sorptivity $\left(K_{\mathrm{oc}}\right)$ and persistence (soil half-life). Data are included only for those pesticides that are reported to have been used in the counties where these study sites are located (Capel et al., 2008) (these diagrams are similar to that used by Barbash and Resek (1996) to examine national data on pesticide occurrence in ground water). In general, the parent pesticides that were detected in the unsaturated zone water samples during this study are clustered in a group characterized by relatively low $K_{\text {oc }}$ values $\left(<200 \mathrm{~mL} \mathrm{~g}^{-1}\right.$ OC) and long half-lives in soil ( $\left.>20 \mathrm{~d}\right)$. Conversely, pesticides with shorter half-lives and/or higher $K_{\text {oc }}$ values were 
generally not detected. However, another pesticide-specific factor determining potential transport of pesticides to the subsurface is use intensity, which was not considered in this simple analysis.

Temporal and Spatial Changes in Metolachlor Concentrations. Spatial and temporal patterns of occurrence are likely to vary among different pesticides and their degradates in the unsaturated zone. This is particularly evident from the occurrence data from this study for metolachlor and two of its degradates, metolachlor ESA and metolachlor OXA. This section focuses on the spatial patterns of occurrence for these three compounds despite the fact that there seems to be little information in the published literature on the relative persistence of the two degradates other than that reported by Krutz et al. (2006).

The molar concentrations of metolachlor and its ESA and OXA degradates (Table 2) were used to calculate the degradate fraction (Eq. [1]) for metolachlor ESA. Because metolachlor was detected in only a few locations-most notably the shallow NE East sites (N22a, N23a, and N23b)—spatial variations in the metolachlor ESA fraction resulted primarily from variations in the relative amounts of metolachlor ESA and OXA, rather than those of the parent compound.

The metolachlor ESA fractions increased with depth at the MD sites (Fig. 4). At the M20 site, for example, the metolachlor ESA fraction increased from a mean of 0.3 at the $0.6-\mathrm{m}$ depth to a mean of 0.9 at the 4.3 -m depth (Fig. 4a). This relation was found to follow a simple linear regression of metolachlor ESA fraction vs. depth that was statistically significant $\left(R^{2}=0.934 ; P<0.001 ; n=\right.$ 12). Similarly, at Site M22, the metolachlor ESA fraction exhibited a significant, positive relation with depth (Fig. 4b), ranging from a mean of 0.5 at $0.6 \mathrm{~m}$ to a mean of 0.9 at $9.1 \mathrm{~m}\left(R^{2}=0.553\right.$; $P=0.004 ; n=18)$. No significant changes in the metolachlor ESA fraction were observed with depth at the IN sites I30 or I32 $(P>0.05)$. In Nebraska, while a significant increase in the metolachlor ESA fraction was observed at NE Site N20 from 0.4 to $0.9\left(R^{2}=0.6667 P=0.0250\right)$, values were generally lower at the NE Sites N22 (0.1-0.4) and N23 (0.27-0.34) and did not change with depth (data not shown). The NE East sites had more recent applications of metolachlor than the other sites (MD or IN).

In several locations, the metolachlor ESA fractions were observed to increase with time at a given depth in the unsaturated zone, with the shallow lysimeters at all sites showing larger increases over time than the deeper lysimeters for the same sites. For example, at NE Site N23a, the metolachlor ESA fraction increased from 0.2 to 0.4 between May and August 2004 (Fig. 5a). A simple linear regression of metolachlor ESA fraction versus date at this site indicated that this increase was statistically significant $\left(R^{2}=0.679\right.$; $P=0.0119 ; n=8)$. In deeper lysimeters, however, the metolachlor ESA fraction was found to be relatively constant over time $(P>0.05)$. Similarly, while the metolachlor ESA fraction appeared to increase slightly over time in the M20 lysimeters (Fig. 5B), none of these increases were statistically significant $(P>0.05)$.

The changes in the relative concentrations of these two metolachlor degradates might be the result of a shorter half-life of one compound relative to the other (Krutz et al., 2006) or different
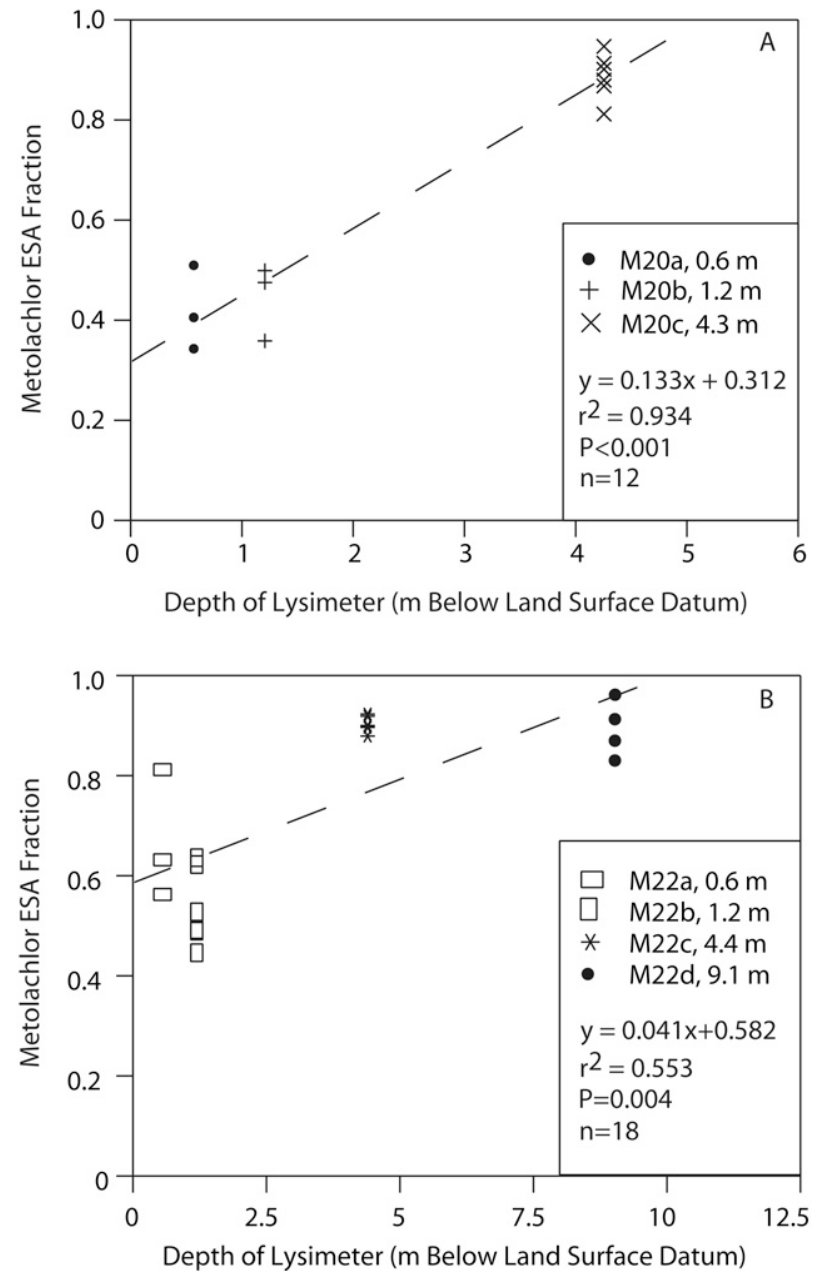

Fig. 4. Metolachlor ethane sulfonic acid (ESA) fraction (Eq. [1]) versus lysimeter depth at two Maryland sites. (A) Site M20. (B) Site M22. Different data points at each depth represent different sampling dates.

sorption characteristics that affect their relative rates of transport. Krutz et al. (2004) found that $K_{\text {oc }}$ values for metolachlor ESA and OXA in cultivated soil were virtually the same (29.8 and $30.6 \mathrm{~mL} \mathrm{~g}^{-1}$ OC, respectively). By calibrating RZWQM predictions to fit field observations at the MD site, Bayless et al. (2008) also obtained $K_{\text {oc }}$ values that were nearly identical for the two compounds $\left(13.5 \mathrm{~mL} \mathrm{~g}^{-1} \mathrm{OC}\right.$ for metolachlor ESA and $17.0 \mathrm{~mL} \mathrm{~g}^{-1}$ OC for metolachlor OXA). Because they were obtained for one of the sites examined for this study, the $K_{\text {oc }}$ values of Bayless et al. (2008) were used with no further adjustments by Webb et al. (2008) for the LEACHM simulations discussed below.

By fitting the BSFOD model to temporal variations in the observed fractions for metolachlor and its ESA and OXA degradates in lysimeter N22b at the focused-recharge site lysimeter at the NE East site, Webb et al. (2008) calculated soil aerobic half-lives for metolachlor ESA and OXA of 70 and 50 $\mathrm{d}$, respectively; these values are consistent with the observation by Krutz et al. (2006) that metolachlor OXA undergoes mineralization in soil more rapidly than metolachlor ESA. Use of this procedure also yielded estimated half-lives of $11 \mathrm{~d}$ for atrazine, $241 \mathrm{~d}$ for DEA, and $23 \mathrm{~d}$ for metolachlor. 
Taken together, these results suggest that the observed increases in the metolachlor ESA fractions with time are primarily a consequence of a faster transformation rate for metolachlor OXA than for ESA, rather than any substantial difference in the mobilities $\left(K_{\mathrm{oc}}\right)$ of the two compounds. In addition, the observed changes in the metolachlor ESA fraction with time and depth are consistent with the loss of the (apparently) more labile metolachlor OXA at shallower depths in the subsurface, where the microbial community is likely to be more active. Over time, this would lead to increases in the fraction of metolachlor ESA that is present in the soils and, by inference, transported to greater depths in the unsaturated zone. The concentrations of metolachlor ESA and OXA at shallower depths were found to increase throughout the year (Fig. 5), although the increase for metolachlor ESA was greater than that for metolachlor OXA (data not shown). At greater depths, the rates of production of these degradates were lower, perhaps because of diminished microbial activity.

Comparisons among the different study sites indicated that the relative concentrations of metolachlor ESA and OXA also varied in ways that were consistent with faster degradation of metolachlor OXA relative to metolachlor ESA (Fig. 6). At the NE East site, which experienced the most recent applications of metolachlor (in 2004, during the year of sampling), the molar concentrations of metolachlor OXA were about twice those of metolachlor ESA in the shallow lysimeters (N22a, N22b, and N23a) (Fig. 6a and $6 \mathrm{~b})$, suggesting a roughly twofold higher rate of formation of metolachlor OXA relative to metolachlor ESA. For the deeper lysimeter (N23b), the ratio of metolachlor OXA to ESA concentrations is about unity. At the MD sites, metolachlor had been applied more than 2 yr before sampling, and metolachlor ESA was nearly always present at concentrations higher than those of metolachlor OXA, especially in the deepest lysimeters (M22c and M22d) (Fig. 6c). At shallower depths, the ratio of metolachlor OXA to ESA was usually closer to unity. Although other factors, such as different microbial communities and different loading of metolachlor in the different areas, could also be important, these differences in metolachlor ESA fractions seem to reflect the greater persistence of metolachlor ESA relative to the OXA degradate.

Export from the Unsaturated Zone. The potential for a pesticide to leach through the unsaturated zone to ground water depends in part on the recharge rate or residence time of water. Table 2 presents the pesticide flux estimates at various depths within the unsaturated zone for the triazine and acetanilide parent compounds and for several of their degradates. At each lysimeter for which they were estimated, fluxes were zero where no parent or degradate compound was detected or where mean concentrations were zero. The resulting flux estimates were observed to vary over several orders of magnitude. The highest fluxes calculated were those for the sites with the highest concentrations of pesticides and degradates, with the highest value being obtained for lysimeter N22b at the NE East site.

The LEACHM simulations were used to estimate recharge rates at the MD M22 site (Webb et al., 2008). At this site, a calibrated LEACHM model predicted a recharge rate of $0.11 \mathrm{~m} \mathrm{yr}^{-1}$, which was in close agreement with the recharge rate of $0.32 \mathrm{~m} \mathrm{yr}^{-1} \mathrm{calcu}-$
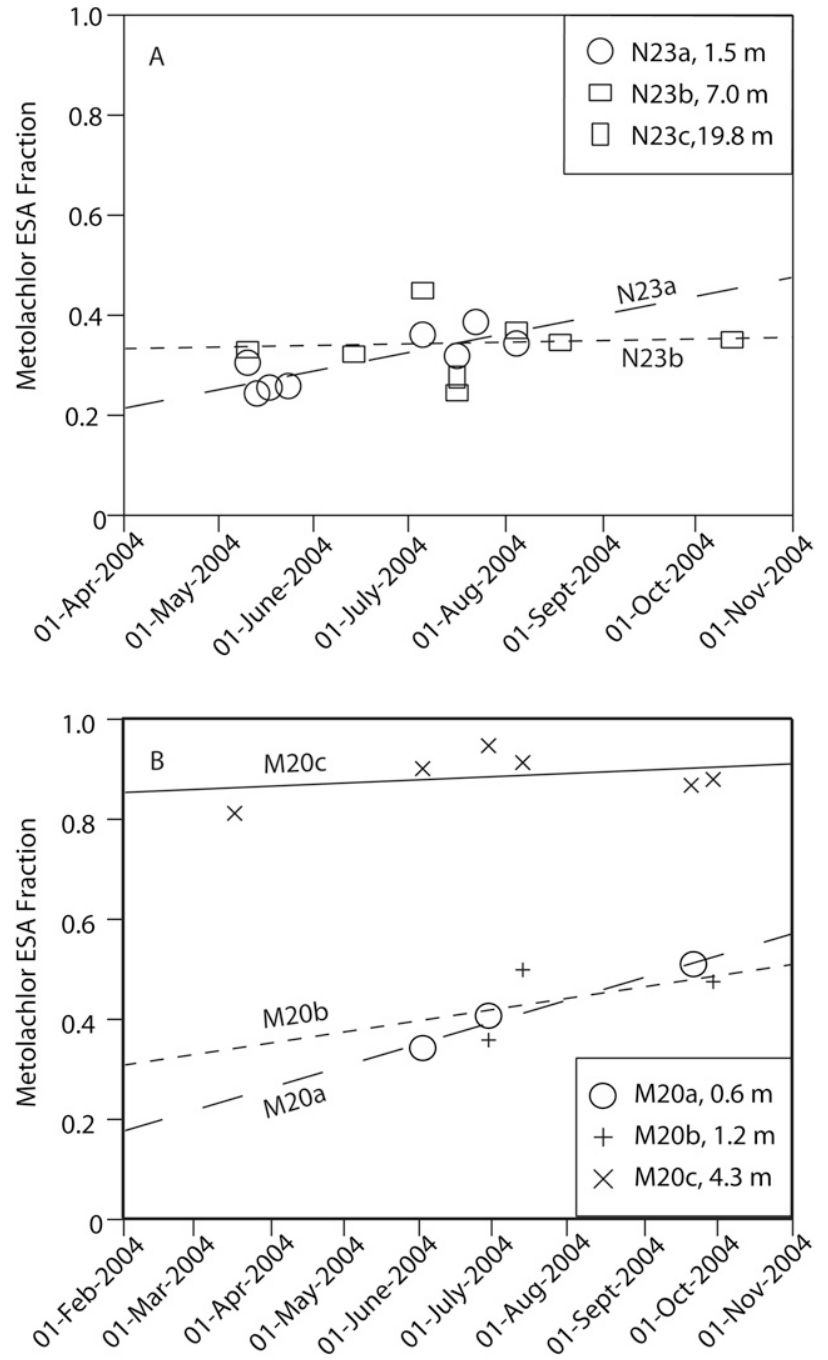

Fig. 5. Metolachlor ethanesulfonic acid (ESA) fraction (Eq. [1]) versus time at two study sites. (A) Nebraska Site N23. (B) Maryland Site M20.

lated by Fisher and Healy (2008). Using the LEACHM-derived recharge rate and observed mean concentrations for metolachlor ESA, metolachlor OXA, and DEA at the deepest lysimeter, flux estimates of 1.0, 0.11, and $0.024 \mu \mathrm{mol} \mathrm{m}^{-2} \mathrm{yr}^{-1}$, respectively, were obtained. These values were in relatively close agreement with those calculated directly from the lysimeter data (3.0, 0.32, and $0.07 \mu \mathrm{mol} \mathrm{m}{ }^{-2} \mathrm{yr}^{-1}$, respectively) (Table 2 ).

The flux estimates calculated for this study for some degradates changed with depth in the unsaturated zone column for some sites (Table 2). The flux of DEA increased with depth at MD Sites M21 and M22 and decreased with depth at IN Sites I30 and I32. At the MD sites, atrazine seemed to be forming DEA throughout the unsaturated zone, whereas at IN, a shallow static water table and flooding of the unsaturated zone may flush chemicals over time, leading to lower concentrations with depth.

The fluxes of acetochlor ESA and OXA increased with depth at the WA site to $2.8 \mathrm{~m}$ (W22j); however, there was more variability in the flux of these compounds at the IN sites. Alachlor ESA and OXA concentrations did not change appreciably with depth at 


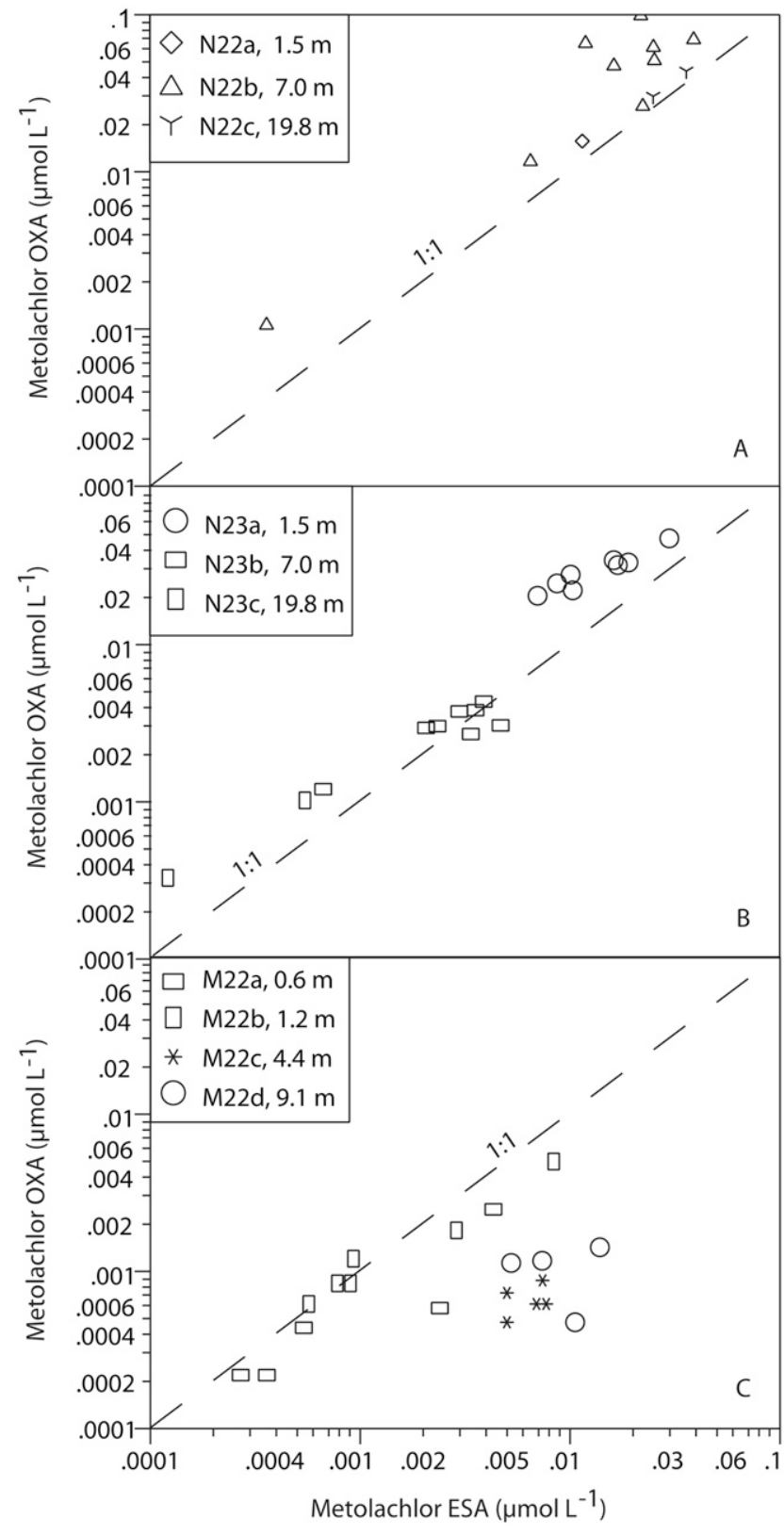

Fig. 6. Comparison of concentrations of metolachlor oxanilic acid (OXA) and metolachlor ethanesulfonic acid (ESA) at three study sites: (A) Nebraska East Site N22, (B) Nebraska East Site N23, and (C) Maryland Site M22.

the IN and WA sites. Acetochlor and alachlor may have been used more recently at the IN and WA sites than at the other sites; however, no information was available from local growers to evaluate this hypothesis. At MD Site M20, the fluxes of acetochlor ESA and OXA and of alachlor ESA and OXA were found to decrease with depth. The M20 site may be affected by a different hydrogeologic matrix and water flow pattern more than the other MD sites. The flux of metolachlor ESA increased with depth for many sites, including both IN sites, MD Sites M21 and M22, and NE East Site N22, whereas the flux of metolachlor OXA increased only at MD Site M20. Consistent with the earlier discussion, metolachlor ESA seems to be longer-lived than metolachlor OXA, and these results are consistent with the general loss of metolachlor OXA observed at shallower depths in the subsurface. Over time and at most sites, more metolachlor ESA was found to remain in the soils and to be transported through the unsaturated zone to the ground water (Steele et al., 2008) than was the case for metolachlor OXA.

\section{Acknowledgments}

This research was supported by the U.S. Geological Survey (USGS), National Water-Quality Assessment (NAWQA) Program. The authors thank William Foreman (USGS) for the analytical assistance and interpretative guidance. We also thank William Guertal, Judith Denver, and Richard Healy (USGS) for helping with site selection and study design. Numerous USGS employees assisted with installation, sample collection, and data management, and their involvement in the successful completion of the project was invaluable.

\section{References}

Ahuja, L.R., K.W. Rojas, J.D. Hanson, M.J. Shaffer, and L. Ma (ed.) 2000. The Root Zone Water Quality Model. Water Resources Publ. LLC, Highlands Ranch, CO.

Barbash, J.E., and E.A. Resek. 1996. Pesticides in ground water: Distribution, trends, and governing factors. CRC Press, Boca Raton, FL.

Barbash, J.E., G.P. Thelin, D.W. Kolpin, and R.J. Gilliom. 1999. Distribution of major herbicides in ground water of the United States. U.S. Geological Survey Water-Resources Investigations Rep. 98-4245. Available at http://water.usgs.gov/nawqa/pnsp/pubs/wrir984245/ (verified 9 Mar. 2008).

Barbash, J.E. (2007). The geochemistry of pesticides. In B.S. Lollar et al. (ed.) Environmental geochemistry. Volume 9 of Treatise on Geochemistry. Elsevier-Pergamon, Oxford, UK. Available at http://water.usgs.gov/ nawqa/pnsp/pubs/files/Geochemistry_of_Pesticides-Barbash_2007c.pdf (verified 7 Mar. 2008).

Bayless, E.R., P.D. Capel, J.E. Barbash, R.M. Webb, T.C. Hancock, and D.C. Lampe. 2008. Simulated fate and transport of metolachlor in the unsaturated zone, Maryland, USA. J. Environ. Qual. 37:1064-1072.

Bergström, L., and J. Stenström. 1998. Environmental fate of chemicals in soil. Ambio 27:16-23.

Capel, P.D., K.A. McCarthy, and J.E. Barbash. 2008. National, holistic, watershed-scale approach to understand the sources, transport, and fate of agricultural chemicals. J. Environ. Qual. 37:983-993.

Delin, G.N., and M.K. Landon. 2002. Effects of topography on the transport of agricultural chemicals to groundwater in a sand-plain setting. Hydrogeol. J. 10:443-454.

Domagalski, J.L., S.W. Ator, R.H. Coupe, K.A. McCarthy, D.C. Lampe, M.W. Sandstrom, and N.T. Baker. 2008. Comparative study of transport processes of nitrogen, phosphorus, and herbicides to streams in five agricultural basins, USA. J. Environ. Qual. 37:1158-1169.

Fisher, L.H., and R.W. Healy. 2008. Water movement within the unsaturated zone in four agricultural areas of the United States. J. Environ. Qual. 37:1051-1063.

Flury, M. 1996. Experimental evidence of transport of pesticides through field soils: A review. J. Environ. Qual. 25:25-45.

Fredrick, B.S., J.I. Linard, and J.L. Carpenter. 2006. Environmental setting of the Maple Creek Watershed, Nebraska. U.S. Geological Survey Scientific Investigations Rep. 2006-5037. USGS, Lincoln, NE.

Gevao, B., C. Mordaunt, K.T. Semple, T.G. Piearce, and K.C. Jones. 2001. Bioavailability of nonextractable (bound) pesticide residues to earthworms. Environ. Sci. Technol. 35:501-507.

Gilliom, R.J., J.E. Barbash, C.G. Crawford, P.A. Hamilton, J.D. Martin, N. Nakagaki, L.H. Nowell, J.C. Scott, P.E. Stackelberg, G.P. Thelin, and D.M. Wolock. 2006. The quality of our nation's waters - Pesticides in the nation's streams and ground water, 1992-2001. U.S. Geological Survey Circ. 1291. Available at http://pubs.usgs.gov/circ/2005/1291/ (verified 7 Mar. 2008).

Gronberg, J.M., and C.R. Kratzer. 2006. Environmental setting of the Lower Merced River Basin, California. U.S. Geological Survey Scientific Investigations Rep. 2006-5152. Available at http://pubs.water.usgs.gov/ 
sir2006-5152/ (verified 3 Mar. 2008).

Gustafson, D.I. 1993. Pesticides in drinking water. Van Nostrand Reinhold, New York, NY.

Hallberg, G.R. 1989. Pesticide pollution of groundwater in the humid United States. Agric. Ecosyst. Environ. 26:299-367.

Hamaker, J.W., and J.M. Thompson. 1972. Adsorption p. 49-143. In C.A.I. Goring and J.W. Hamaker (ed.) Organic chemicals in the soil environment, Volume 1. Marcel Dekker, Inc., New York, NY.

Hancock, T.C., and M.J. Brayton. 2006. Environmental setting of the Morgan Creek Basin, Maryland, 2002-04. U.S. Geol. Surv. Open-File Rep. 2006-1151. USGS, Baltimore, MD.

Hladik, M.L., J.J. Hsiao, and A.L. Roberts. 2005. Are neutral chloroacetamide herbicide degradates of potential environmental concern? Analysis and occurrence in the upper Chesapeake Bay. Environ. Sci. Technol. 39:6561-6574.

Hutson, J.L., and R.J. Wagenet. 1992. LEACHM: Leaching Estimation and Chemistry Model: A process-based model of water and solute movement, transformations, plant uptake and chemical reactions in the unsaturated zone continuum, v.2, Version 3. Water Resources Inst., Cornell Univ., Ithaca, NY.

Hutson, J.L. 2005. LEACHM: Leaching Estimation and Chemistry Model: A process-based model of water and solute movement, transformations, plant uptake, and chemical reactions in the unsaturated zone. Model Description and User's Guide, Version 4.1 May 2005.

Iqbal, M.Z. 1999. Role of macropores in solute transport under ponded water condition produced by laboratory simulated intense storms. Ground Water 37:674-681.

Kiely, T., D. Donaldson, and A. Grube. 2004. Pesticides industry sales and usage: 2000 and 2001 market estimates. 733-R-04-001. USEPA, Washington, DC. Available at http://www.epa.gov/oppbead1/ pestsales/01pestsales/market_estimates2001.pdf (verified 7 Mar. 2008).

Kjaer, J., M. Ullum, P. Olsen, P. Sjelborg, A. Helweg, B. Mogensen, F. Plauborg, J.O. Jorgensen, B.V. Iversen, I. Fomsgaard, and B. Lindhardt. 2001. The Danish Pesticide Leaching Assessment Programme: Monitoring results May 1999-June 2001, second report. Geological Survey of Denmark and Greenland, Copenhagen, Denmark. Available at http://pesticidvarsling.dk/xpdf/plap2_report_may-2002.pdf (verified 7 Mar. 2008).

Krutz, L.J., T.J. Gentry, S.A. Senseman, I.J. Pepper, and D.P. Tierney. 2004. Adsorption and desorption of metolachlor and metolachlor metabolites in vegetated filter strip and cultivated soil. J. Environ. Qual. 33:939-945.

Krutz, L.J., S.A. Senseman, K.J. McInnes, D.W. Hoffman, and D.P. Tierney. 2006. Mineralisation of atrazine, metolachlor, and their respective metabolites in vegetated filter strip and cultivated soil. Pest Manage. Sci. 62:505-514.

Lathrop, T.R. 2006, Environmental setting of the Sugar Creek and Leary Weber Ditch Basins, Indiana, 2002-04. U.S. Geological Survey Scientific Investigations Rep. 2006-5170. Available at http://pubs.usgs. gov/sir/2006/5170/ (verified 3 Mar. 2008).
Lesan, H.M., and A. Bhandari. 2003. Atrazine sorption on surface soils: Time-dependent phase distribution and apparent desorption hysteresis. Water Res. 37:1644-1654.

Lee, E.A., and A.P. Strahan. 2003. Methods of analysis by the U.S. Geological Survey Organic Geochemistry Research Group_-Determination of acetamide herbicides and their degradation products in water using online solid-phase extraction and liquid chromatography/mass spectrometry. U.S. Geological Survey Open-File Report 03-173. USGS, Washington, DC.

Mackay, D., W.Y. Shiu, and K.C. Ma. 1997. Illustrated handbook of physical chemical properties and environmental fate for organic chemicals. Vol. 5. Pesticide chemicals. Lewis Publ./CRC Press, New York, NY.

McMahon, P.B., K.F. Dennehy, B.W. Bruce, J.K. Böhlke, R.L. Michel, J.J. Gurdak, and D.B. Hurlbut. 2006. Storage and transit time of chemicals in thick unsaturated zones under rangeland and irrigated cropland, High Plains, United States. Water Resour. Res. 42:W03413, doi:10.1029/2005WR004417.

Nakagaki, N., and D.M. Wolock. 2005. Estimation of agricultural pesticide use in drainage basins using land cover maps and county pesticide data. U.S. Geol. Surv. Open-File Rep. 2005-1188. USGS, Sacramento, CA.

Nolan, B.T., R.W. Healy, P.E. Taber, K. Perkins, K.J. Hitt, and D.M. Wolock. 2006. Factors influencing ground-water recharge in the eastern United States. J. Hydrol. doi: 10.1016/j.jhydro.2006.06.029.

Payne, K.L., H.M. Johnson, and R.W. Black. 2007. Environmental setting of the Granger Drain and DR2 Basins, Washington 2003-2004. U.S. Geological Survey Scientific Investigations Rep. 2007-5102. USGS, Washington, DC.

Roy, W.R., and I.G. Krapac. 1994. Adsorption and desorption of atrazine and deethylatrazine by low organic carbon geologic materials. J. Environ. Qual. 23:549-556.

Seybold, C.A., and W. Mersie. 1996. Adsorption and desorption of atrazine, deethylatrazine, deisopropylatrazine, hydroxyatrazine, and metolachlor from two soils in Virginia. J. Environ. Qual. 25:1179-1185.

Stamper, D.M., and O.H. Tuovinen. 1998. Biodegradation of the acetanilide herbicides alachlor, metolachlor, and propachlor. Crit. Rev. Microbiol. 24:1-22.

Steele, G.V., H.M. Johnson, M.W. Sandstrom, P.D. Capel, and J.E. Barbash. 2008. Occurrence and fate of pesticides in four contrasting groundwater flow systems. J. Environ. Qual. (in press).

Tasli, S., L. Patty, H. Boetti, P. Ravanel, G. Vachaud, C. Scharff, J. FavreBonvin, M. Kaouadji, and M. Tissut. 1996. Persistence and leaching of atrazine in corn culture in the experimental site of La Côte Saint André (Isère, France). Arch. Environ. Contam. Toxicol. 30:203-212.

Vogel, J.R., M.S. Majewski, and P.D. Capel. 2008. Pesticides in rain in four agricultural watersheds in the United States. J. Environ. Qual. 37:1101-1115.

Webb, R.M.T., M.E. Wieczorek, B.T. Nolan, T.C. Hancock, M.W. Sandstrom, E.R. Bayless, R.W. Healy, and J.I. Linard. 2008. Variations in pesticide leaching related to land use and unsaturated zone thickness in an agricultural watershed in Maryland. J. Environ. Qual. (in press). 